\title{
Cytology of Chlamydospore Development in Protomycopsis Species
}

\author{
M. P. Haware and M.S. Pavgi \\ Faculty of Agriculture, Banaras Hindu University, India
}

Received October 30, 1974

\section{Introduction}

Members of the genus Protomycopsis Magnus are parasitic on higher plants. Magnus (1905) described the formation of chlamydospores (resting spores) as terminal in Protomycopsis leucanthemi Magnus parasitic on Chrysanthemum leucanthemum L. Büren $(1915,1922)$ observed the development of chlamydospores in few species of Protomycopsis. Protomycopsis patelii Pavgi and Thirumalachar (1953) parasitic on mung beans (Phaseolus mungo L. and Phaseolus radiatus L.) and Protomycopsis thirumalacharii Pavgi (1965) parasitizing 'agasta' (Sesbania grandiflora Pers.) are of common occurrence in Varanasi, U. P. No details of the process of chlamydospore development in the host tissue in any species of Protomycopsis are available in literature. Present investigations were carried out to add to our knowledge of chlamydospore development in the host tissues and nuclear behavior during the process.

\section{Materials and methods}

Leaflets of Phaseolus mungo L. and Sesbania grandiflora Pers. respectively bearing the infection spots of Protomycopsis patelii Pavgi and Thirumalachar and $P$. thirumalacharii Pavgi were collected from the field in September and stored at room temperature $\left(24-26^{\circ} \mathrm{C}\right)$. Mature chlamydospores were separately drawn from the spots and induced to germinate on plated potato dextrose agar medium $(\mathrm{pH}$ 6.5) (Pavgi and Haware 1970a). Local varieties of Phaseolus mungo and Sesbania grandiflora susceptible to the respective species of Protomycopsis were grown in isolation in a pot house in partially sterilized soil. One month old seedlings were sprayed with a culture cell suspension of uniform density in sterile dist. water prepared from 10-day old plated colonies of the pathogens grown on potato dextrose agar (Pavgi and Haware 1970a). The seedlings were retained in a moisture chamber for $48 \mathrm{hrs}$, then removed and placed in the open.

During the first $48 \mathrm{hrs}$ epidermal peels were removed at short intervals from the inoculated surface of the leaflets and studied in whole mounts in lactophenol stained with cotton blue or carbol fuchsin. Two days after inoculation small pieces from the inoculated leaflets were cut and fixed in Randolph's modified Navashin fluid and weak chrom-acetic soln. Material was kept for $12 \mathrm{hrs}$ in the fixing fluid, washed thoroughly in running water for $2 \mathrm{hrs}$, passed through an ascending series of alcohol, alcohol: xylol and finally embedded in paraffin. Serial sections were microtomed 
(8-10 $\mu)$ and stained with Heidenhain's iron hematoxylin and saffranin and counterstained with light green or orange $G$ as necessary (Johansen 1940, Sass 1967). Free hand sections of fresh infected material were prepared for complementary observations.

\section{Observations}

Leaflets of the 2 hosts-Phaseolus mungo L. and Sesbania grandiflora Pers. respectively inoculated with Protomycopsis patelii and Protomycopsis thirumalacharii, were incubated in a moisture chamber, which tended to lower the temperature than outside. Comparable conditions prevailed in the field during nightfall and in the early morning hours. Epidermal peels removed at short intervals during the first $48 \mathrm{hrs}$ showed that the diploid vegetative cells and/or conidia developed on short hyphal branches in artificial cultures germinated within 3-4 hrs (Haware 1969), and the slender, infective hyphae penetrated the epidermis within $24 \mathrm{brs}$. No hyphal penetration through the stomatal openings was observed. The multinucleate vegetative cell or conidium gave rise to a fine germ tube from a terminal end into which most of the cytoplasm along with the diploid nuclei moved, leaving the cell almost vacuolate. The germ tube slightly dialated before penetrating the cuticle and pierced the cuticle without forming an appressorium (Figs. 1, 2, 12, 13). No septa were formed to prevent backflow of the protoplasm into the vacuolate hyphae that appeared collapsed. The hyphae branched in the interspaces of the mesophyll, radiated in all directions and became septate (Figs. 3, 4, 14-16). They grew more luxuriantly in the interspaces of the spongy mesophyll, but irregularly in shape in the palisade tissue.

Older hyphae became closely septate upto terminal portions and difficult to detect as they failed to take the stain. Young hyphae were multinucleate; the diploid nuclei appeared dark stained and closer where hyphal branches initiated (Figs. 4, $5,17)$. The hyphae grew closely appressed to the cell walls of the mesophyllar tissue, but no haustoria were observed. The chloroplasts of the mesophyll appeared reduced both in number and size and the protoplasm appeared to disintegrate in the parenchymatous cells. Nuclei in the cells in contact with hyphae had disappeared. The cell walls crumpled and the cells became largely vacuolate lined with thin peripheral protoplasmic layers. Ramification of the hyphae was mostly restricted to the parenchymatous tissue (Figs. 4, 5). Details of mitotic nuclear divisions in the hyphae were not observed. The divisions took place with spindles oriented parallel to the axis of the hyphae. It appeared that the chromatin material elongated, constricted in the middle and separated to form 2 daughter nuclei. No individual chromosomes could be discerned.

The mycelial development remained restricted to localized areas. The parasitic hyphae did not invade the vascular bundles. The host cells around the infection site were dead or near collapse. Terminal cells of the short hyphal branches enlarged and the cytoplasm and nuclei appeared more prominent in them (Figs. 6, 7, 18). The single nucleus which migrated into the enclosed sporogenous cell divided into 2 . The cytoplasm moved up leaving the parent cell almost vacuolate, while the terminal sporogenous cells were dense in protoplasm containing 1 or 2 vacuoles of short 

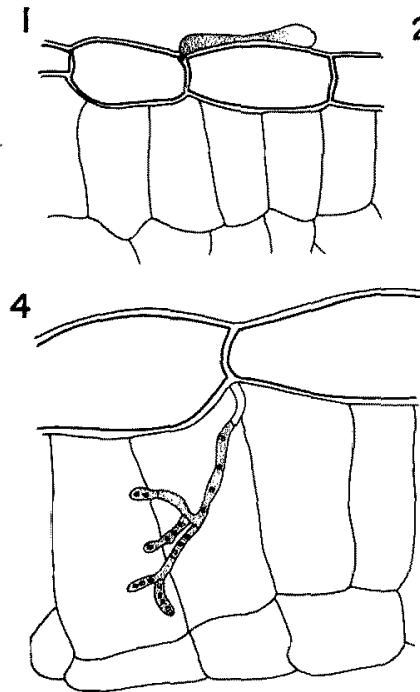

7

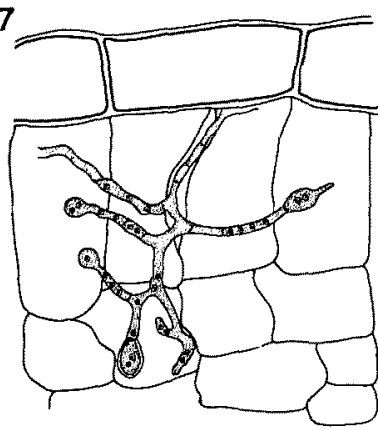

9

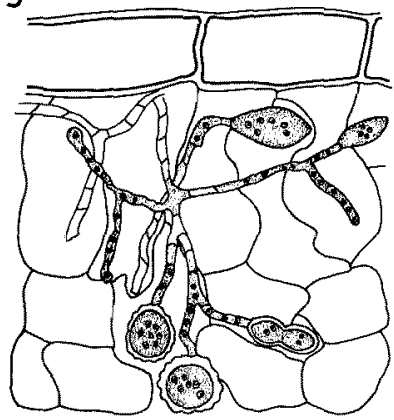

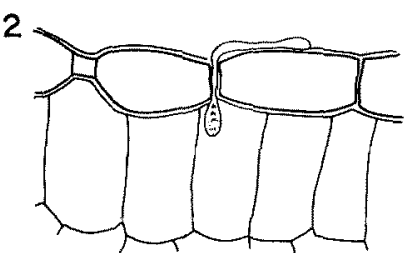

5

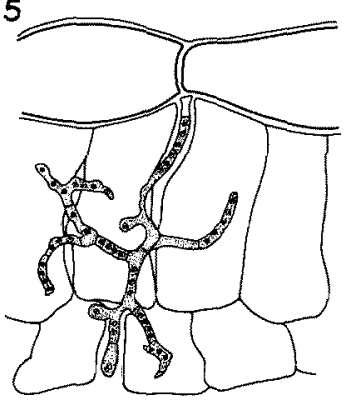

8
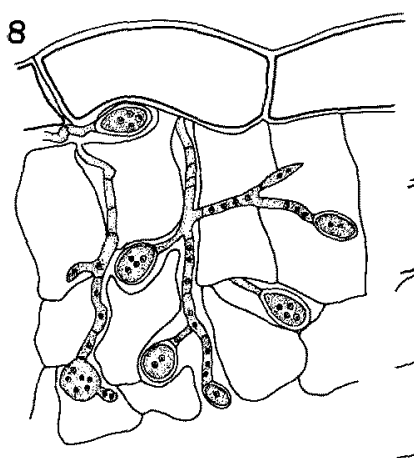

10

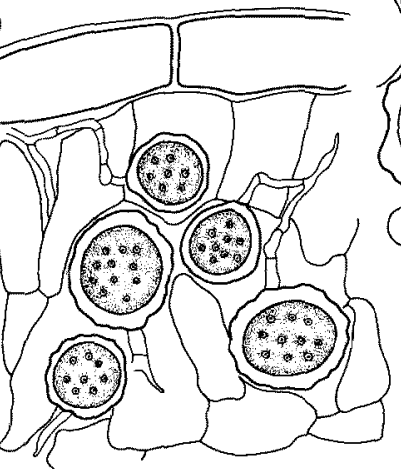

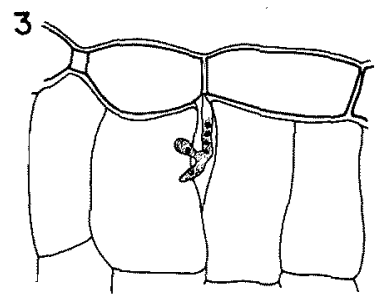

6

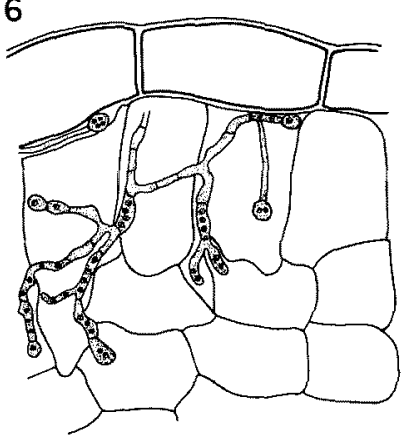

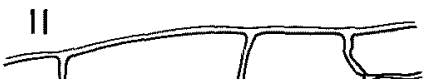
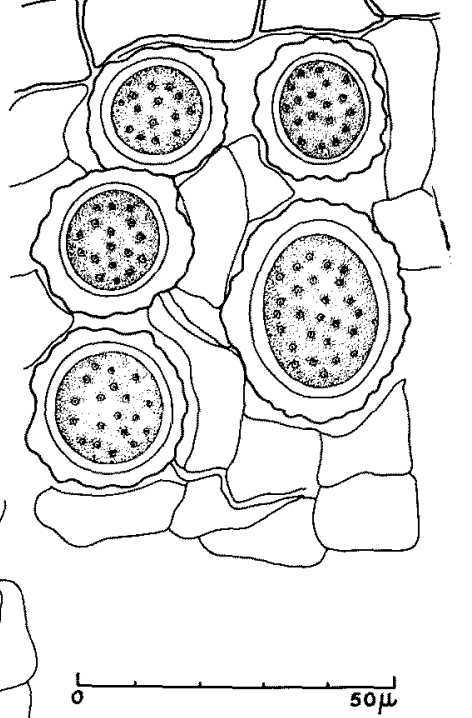

Figs. 1-11. Cytology of chlamydospore development of Protomycopsis patelii. 1, infective hypha lying in contact with the epidermal layer of Phaseolus mungo leaflet. 2, multinucleate infection peg piercing the cuticle and entering between epidermal cells. 3, infective hypha developing in the intercellular spaces of spongy mesophyll. 4, 5, multinucleate, septate hyphae in the intercellular spaces of mesophyll. 6, and 7, terminal, uninucleate cells of hyphal branches becoming round with the division of the diploid nucleus into 2 nuclei. 8, terminal, multinucleate, enlarged sporogenous cells developing in the intercellular spaces of the mesophyll. 9,10 , development of chlamydospores with thick exosporium. 11, mature, multinucleate chlamydospores with thick and warty exosporium and thin endosporium, bearing tail-like hyphal appendages. 

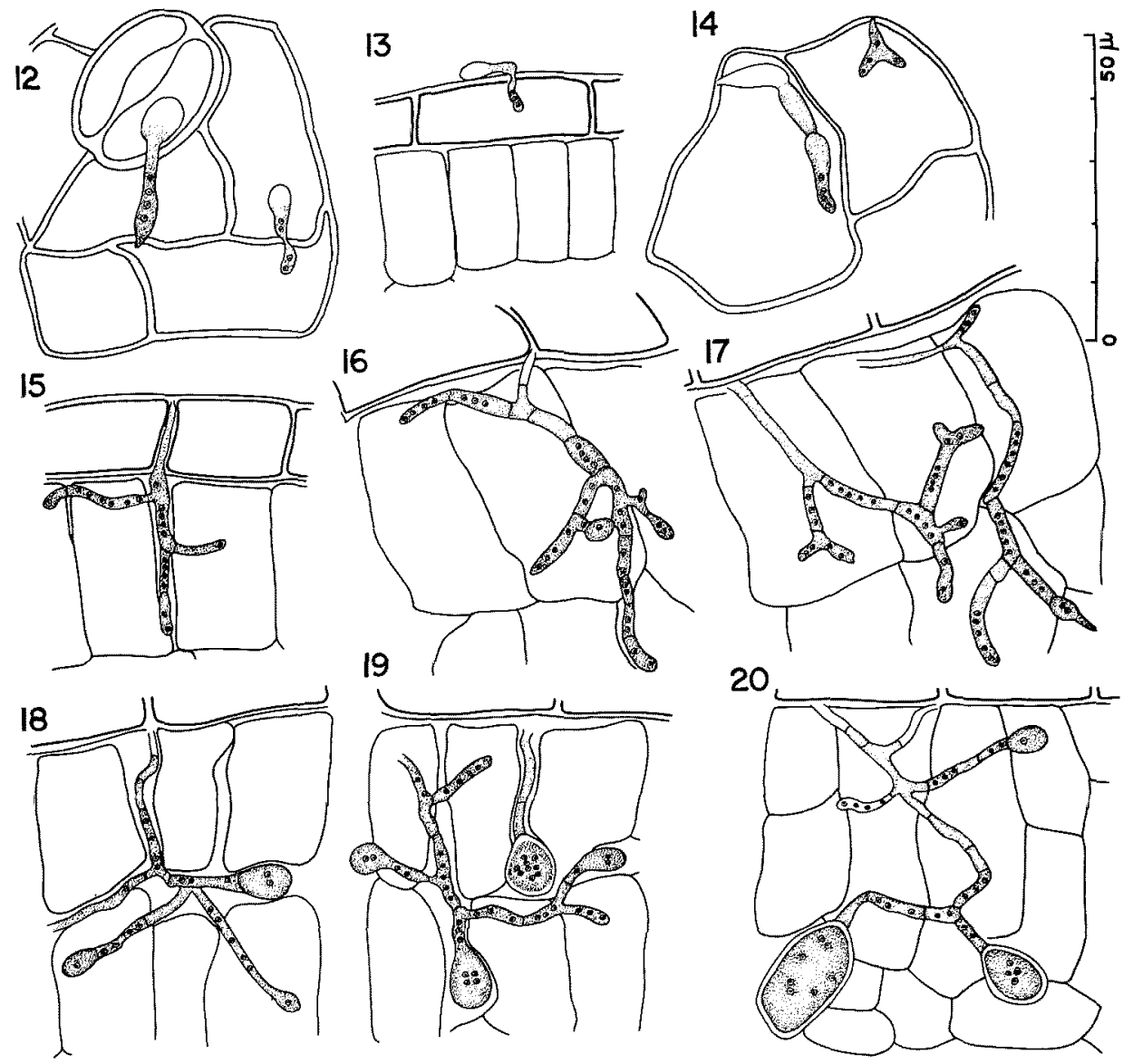

19
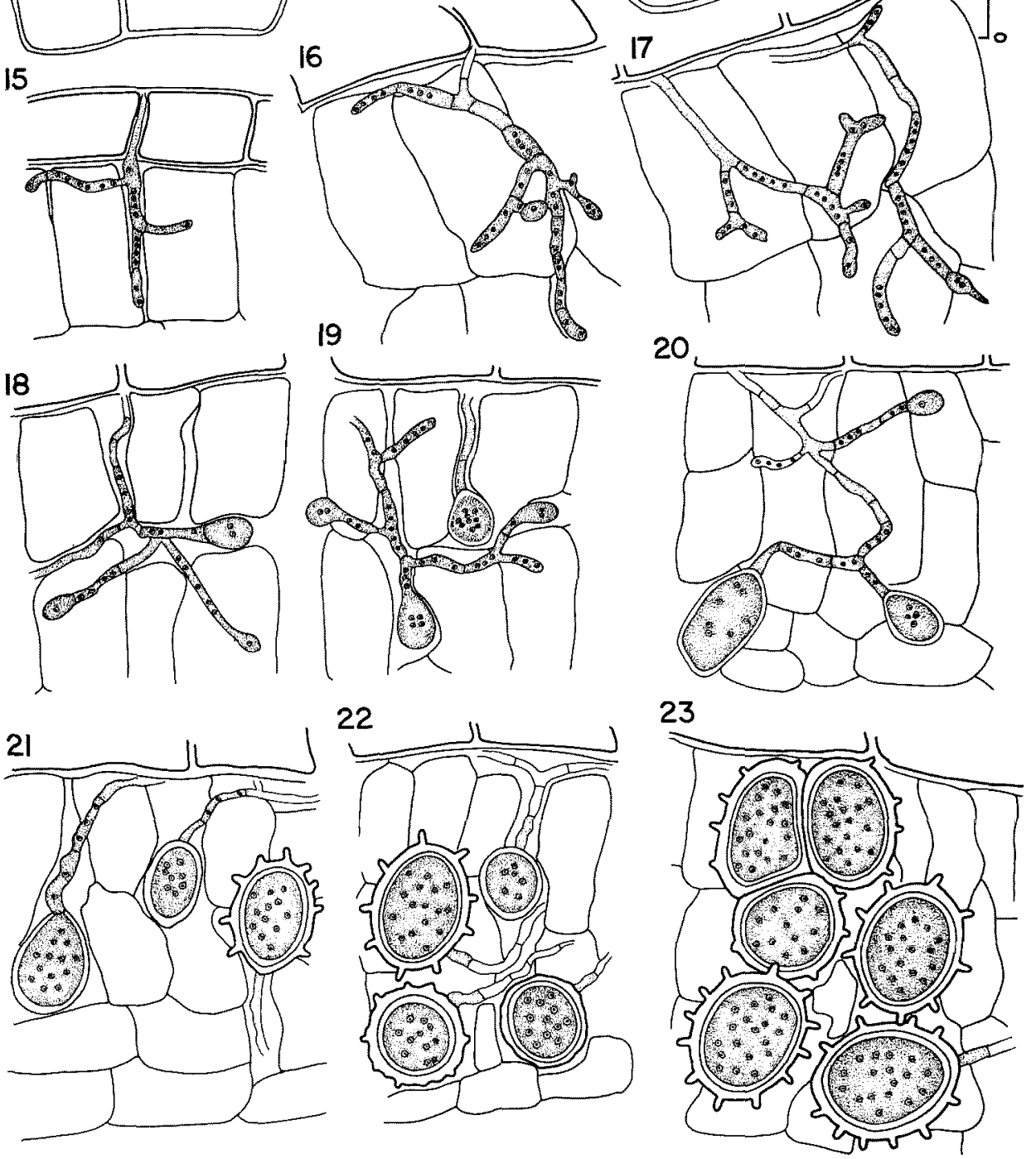

Figs. 12-23. Cytology of chlamydospore development of Protomycopsis thirumalacharii. 12, infective hypha growing on the epidermal layer. 13,14, infection peg piercing the cuticular layer. 15 , infective hypha growing in the intercellular spaces of the spongy mesophyll with short, septate, multinucleate branches. 16,17 , intercellular mycelium in the mesophyll. 18-20, uninucleate and multinucleate terminal cells enlarging and becoming round. 21,22 , terminal cells developing into large, thick-walled, multinucleate chlamydospores in the intercellular spaces. 23, mature chlamydospores with thick episporium, bluntly conical ornamentations, thin endosporium and hyphal appendages. 
duration (Fig. 8). The cell initials were round at first, later enlarged and became multinucleate and globose to pyriform in shape. The host cells were pushed apart due to repeated formation of sporogenous cells in the intercellular spaces (Figs. 19, 20). In the process of spore formation, the inner hyaline wall (mesosporium) became prominent and distinct (Fig. 9) and the outer (hyaline) wall increased in thickness, became amber yellow and later brown to reddish brown, covered with rough blunt warts in $P$. patelii (Fig. 10) and hyaline processes that became light brown to amber brown and bluntly conical (2-6 $\mu$ long) and discontinuous in $P$. thirumalacharii, as the chlamydospores matured. The protoplasm in them increased in density, developed pale yellow to amber brown pigment and became multinucleate. The mature spore wall was differentiated into a thicker exosporium, the middle mesosporium and a thinner membraneous endosporium; the endosporium was differentiated from the protoplasm. The vegetative hyphae were difficult to detect as they disappeared or remained as vegetative appendages attached to the chlamydospores (Figs. 11, 23). The chlamydospores were formed singly, but appeared in aggregates due to crowding and mutual pressure. Mature chlamydospores were deep brown to reddish brown and nearly opaque with further maturation; they measured $22.5-32.5 \mu$ with thick warty exosporium $(4-6 \mu)$ in P. patelii and 18.3$25.4 \mu$ with thick exosporium in $P$. thirumalacharii.

\section{Discussion}

Cytological observations had revealed earlier that copulation between 2 compatible (endo) spores from germinated chlamydospores of Protomycopsis patelii and $P$. thirumalacharii initiated in artificial cultures the development of diploid conidia borne on short hyphal branches (Haware 1969). Inoculation with diploid conidial suspension and mycelial fragments initiated infection of leaflet tissues of Phaseolus mungo and Sesbania grandiflora respectively. Inoculated leaflets were retained in a moisture chamber, which subsequently lowered the surrounding temperature comparable to conditions prevailing in the field during nightfall and in the early morning hours. Although deposition of conidia of $P$. thirumalacharii occurs on leaflets of $S$. grandiflora during periods of positive phototropism under a dry atmosphere (Pavgi and Haware 1970b), the conidial germination apparently occurs following dew deposition in the early morning hours or during a light shower. Infection of the leaflets follows with the hyphae forming multinucleate, septate mycelium in intercellular spaces of the mesophyll. Multinucleate, rough and thickwalled chlamydospores developed terminally on hyphal branches. The diploid (spore) cells developed in artificial cultures by species of Protomyces Unger were similarly found infective (Pavgi and Mukhopadhyay 1969, Valadon et al. 1962). Büren (1915, 1922) observed and described the intercellular, septate and multinucleate mycelium of Protomyces Unger, Protomycopsis Magnus and Taphridium Lagerh. and Juel in host tissues. Diploid nuclei in the hyphal cells divided mitotically and appeared very small. Kramer (1958) noted extremely small nuclei in an allied new genus Mixia Kramer in the family Protomycetaceae. The nuclei of members of Protomycetaceae are characteristically too small to permit critical observations on the 
sequence in the divisional process with presently available techniques.

Basically the process of development of chlamydospores of $P$. patelii and $P$. thirumalacharii was observed to be similar to that in Protomyces except that they were formed as terminal enlargements of the hyphal branches in the genus Protomycopsis, whereas in Protomyces they are also formed intercalary (Büren 1915, Fitzpatrick 1930, Mukhopadhyay and Pavgi 1973). In species of the genera Protomyces and Protomycopsis, they are formed irregularly scattered in the host tissues around the epicenter of infection site. In the genus Taphridium, the chlamydospores are formed only in a layer just below the upper epidermis of the host leaves.

The diploid phase predominates in the life cycle of Protomycopsis species, whereas the haploid phase represented by the endogenous spores from the germinating chlamydospores is relatively short in span (Haware 1969). Similar predominance of the diploid phase is encountered in the allied genus Protomyces (Valadon et al. 1962). The studies confirm the ontogenical characters of the genus Protomycopsis attributed by earlier workers, such as predominance of diploid phase in the life cycle, and terminal development of thickwalled chlamydospores, which are diploid, multinucleate, usually rough-walled or variously ornamented resting bodies, pigmented dark brown almost towards opacity (Bessey 1950, Büren 1915, 1922, Gäumann and Wynd 1952). Their development in the host leaves was nearly identical to that observed in vitro in the artificial cultures (Haware 1969).

Development of haustoria was not observed in any of the species of Protomycopsis studied. Their absence and absorption of nutrition from the host cells through appressed contact of the parasite appear characteristic of all members of the Protomycetaceae in contrast to the haustorial development by several members of the genus Taphrina Fries in the fam. Taphrinaceae (Pavgi and Upadhyay 1967). Despite nondevelopment of haustorial processes within the host cells, disintegration of chloroplasts and nuclei in the cells lying in contact with the intercellular parasitic hyphae has been observed in both the hosts infected by the 2 species of Protomycopsis. This apparently is due to the corrosive or lytic action of a fungal metabolite diffusing through the parenchymatous cells, although no deleterious staining effect was noted in these studies. No development of distortion and/or proliferation of the host tissues in the infection sites was observed in either of the species.

\section{Summary}

Observations on the nuclear behavior during chlamydospore development in Phaseolus mungo L. and Sesbania grandiflora Pers. by Protomycopsis patelii Pavgi and Thirumalachar and Protomycopsis thirumalacharii Pavgi respectively are described in detail. The vegetative cells and/or conidia from diploid mycelia are pathogenic in the 2 species. Numerous chlamydospores typical of the species form the terminal sporogenous cells of the permeating hyphae within the infection epicenter. No vascular infection was noted. No haustoria were developed by any of the species. Pathological effects were observed on the host cells without any stimulation for cell multiplication and enlargement. Comparison was made on chlamydospore development in species of allied genera in the family Protomycetaceae. 


\section{Acknowledgement}

The first author (MPH) expresses his gratitude to the Council of Scientific and Industrial Research, New Delhi for the award of a Junior Research Fellowship.

\section{Literature cited}

Bessey, E. A. 1950. Morphology and Taxonomy of Fungi. The Blakiston Company, Philadelphia. $791 \mathrm{p}$.

Büren, Gunther von. 1915. Die schweizerischen Protomyceteen mit besonderer Berücksichtigung ihrer Entwicklungsgeschichte und Biologie. Beiträge zur Kryptogamenflora der Schweiz. 5: 1-95.

- 1922. Weitere Untersuchungen über die Entwicklungsgeschichte und Biologie der Protomyceteen. Beiträge zur Kryptogamenflora der Schwiz. 5: 1-94.

Fitzpatrick, H. M. 1930. The Lower Fungi Phycomycetes. McGraw Hill Book Comp. Inc., New York. 331 p.

Gäumann, E. A. and Wynd, F. L. 1952. The Fungi. Hafner Publg. Co., New York. 420 p.

Haware, M. P. 1969 . Studies on diseases caused by Protomycopsis species. Ph. D. Thesis, Banaras Hindu University, India. $193 \mathrm{p}$.

Johansen, D. A. 1940. Plant Microtechnique. McGraw Hill Book Co. Inc., New York. 523 p.

Kramer, C. L. 1958. A new genus in the Protomycetaceae. Mycologia 50: 916-926.

Magnus, P. 1905. Die Pilze von Tirol. Vorarlberg und Liechtenstein. Innsbruck. 322-323.

Mukhopadhyay, A. N. and Pavgi, M. S. 1973. Cytology of chlamydospore development in Promyces macrosporus Unger. Cytologia 38: 467-477.

Pavgi, M. S. 1965. A new species of Protomycopsis from India. Experientia $21: 281$.

- and Haware, M. P. 1970a. Artificial culture of two Protomycopsis species from India. Nova Hedw. 19: 323-328.

- and - 1970b. Conidial discharge in Protomycopsis thirumalacharii. Pathol. et Microbiol. 35: 297-301.

- and Mukhopadhyay, A. N. 1969. Artificial culture and in vitro chlamydospore development of Protomyces macrosporus Unger. Pathol. et Microbiol. 33: 287-295.

— and Thirumalachar, M. J. 1953. Angular black spot disease of mung beans. Nature, Lond. 172: 314-315.

- and R. Upadhyay. 1967. Development of haustorium in Taphrina maculans Butler. Cytologia 32: 262-269.

Sass, J. E. 1967. Botanical Microtechnique. Oxford and IBH Publg. Co., New Delhi. 228 p.

Valadon, L. R. G., Manners, T. G. and Myers, A. 1962. Studies on the life history and taxonomic position of Protomyces inundatus Dangeard. Trans. Brit. Mycol. Soc. 45: 573-586. 